\title{
Improving Non-English-Majored College Students' Writing Skills: Combining a Know-Want-Learn Plus Model of Meta-Cognitive Writing Strategy Instruction and Internet-Based Language Laboratory Support
}

\author{
Yougen Lou ${ }^{*}$, Liansong $\mathrm{Wu}^{1}$, Honglian Liu ${ }^{2}$, Liyou Chen ${ }^{3 *}$ \\ ${ }^{1}$ School of Foreign Studies, Yangtze University, Jingzhou, China \\ ${ }^{2}$ Jingzhou Experimental Middle School, Jingzhou, China \\ ${ }^{3}$ School of Economics, Jingzhou, China \\ Email: "louyougen@163.com
}

Received 20 June 2016; accepted 16 August 2016; published 19 August 2016

Copyright (C) 2016 by authors and Scientific Research Publishing Inc.

This work is licensed under the Creative Commons Attribution International License (CC BY). http://creativecommons.org/licenses/by/4.0/

(c) (i) Open Access

\section{Abstract}

This paper reviewed a one-term experiment on integrating internet-based language laboratory (IBLL) in teaching writings kills with the know-want-learn (KWL) plus model to second-year nonEnglish-majored college students from Yangtze University. Subjects in this study consisted of 92 non-English-majored college students in the control group (CG) and 91 non-English-majored college students in the experimental group (EG). The results showed that 1) compared with a teacher-dominated approach for CG, internet-based language laboratory with KWL plus model of meta-cognitive writing strategy instruction for EG did a better job in enhancing students' writing skills; 2) there were significant differences between males in CG and EG, and females in CG and EG; 3) students in EG held the positive response for the combined instruction.

\section{Keywords}

KWL Plus Model, Writing Strategy Instruction, Internet-Based Language Laboratory

\footnotetext{
${ }^{*}$ Corresponding authors.
}

How to cite this paper: Lou, Y.G., Wu, L.S., Liu, H.L. and Chen, L.Y. (2016) Improving Non-English-Majored College Students' Writing Skills: Combining a Know-Want-Learn Plus Model of Meta-Cognitive Writing Strategy Instruction and InternetBased Language Laboratory Support. Open Journal of Social Sciences, 4, 37-44. http://dx.doi.org/10.4236/jss.2016.48005 


\section{Introduction}

Since 1999, universities in China have enlarged their enrollment every year, which has led to a serious shortage of English teachers in most universities in China and to the difficulties to improve non-English-majored college students' English writing ability. However, writing ability is important for non-English-majored college students not only to pass the English examination of College English Test 4 (CET 4) or College English Test 6 (CET 6) also in academic papers' writing. Gains in informative and analytical writing ability are, moreover, taken as a good indicator of the value added by higher education (Benjamin \& Chun, 2003). In order to solve the first problem (the serious shortage of English teachers), large-size classrooms have been utilized in most universities and colleges for English writing teaching. But most non-English-majored college students are short of opportunities to use English writing skills they learned in the large-size classroom. And non-English-majored college students have least opportunity to enhance English writing skill in a teacher-centered classroom. Therefore, internetbased language laboratory (IBLL) was popularly used in teaching non-English-majored college students English in more universities. There were many researches [1]-[3] on language laboratory. IBLL could be served differently in the field of language teaching and language learning, but there was few research on IBLL used in teaching nonEnglish-majored college students' English writing combined with KWL plus model of meta-cognitive writing strategy instruction. KWL plus model will be adopted as the scaffold to enhance non-English-majored college students' writing skills. KWL plus was a fourth-stage instructional process scaffolding learners to reflect on what they know, what they want to know, and what they have Learned during their reading process [4]. In order to solve the second problem (the difficulties to guarantee and improve the quality of college students and colleges' academic level through English reading and writing), the author tried to adopt the KWL plus model of meta-cognitive writing strategy instruction with the support of IBLL in this paper. There were few on combination of KWL plus model of meta-cognitive writing strategy instruction with the support of IBLL.

The purpose of this study was to investigate the impact of integrating BLL in KWL plus model of writing strategy instruction for non-English-majored college students. More specifically, this study attempted to answer the following questions:

1) Compared with a teacher-dominated approach with the control group (CG), has the KWL plus model of meta-cognitive writing strategy instruction through IBLL with the experiment group (EG) done a better job in improving students' writing skills?

2) Are there significant differences between males and females, as a teacher-dominated approach with CG is compared with the KWL plus model of writing strategy instruction in IBLL with EG?

3) What is non-English-majored college students' response towards this combination?

\section{Literature Review}

\subsection{KWL Plus}

KWL is a three-stage instructional framework first designed by Ogle [5] (1986) for teachers to guide students with a systematic approach to their reading processes. In KWL [5], "K" stands for asking students what they know about a topic when the teacher initiates a lesson. During this preliminary discussion, students' prior knowledge is stimulated and different opinions and experiences about the topic are pooled. Such practices allow students to frame key questions they still What to investigate in the current reading-the " $w$ " in KWL. These questions, in turn, encourage learners to plan for the coming reading and monitor their comprehension during the reading process. The "L" represents what students have learned and still need to learn after the reading.

To help students better expand their knowledge and to engage them in reflective thinking while reading, Carr and Ogle [6] (1987) extended the KWL model to include Summary as its fourth part. At this part, students are encouraged to reorganize what they have learned with the assistance of a graphic organizer. Based on the graphic organizer, a final written summary is required as an additional opportunity for students to consolidate their learning. The extended model was later labeled KWL Plus [6] [7].

KWL plus model was originally applied in study on reading, in this study, the author tried to apply KWL plus model in writing.

\subsection{Meta-Cognition}

Composing an extended text appears to require the self-regulation of planning, text generation, and reviewing 
through meta-cognitive control of these processes [8] [9]. Meta-cognition was originally coined by Flavell [10] (1976) to refer to the knowledge and regulation of one's cognition. Later on, in the field of second/foreign language acquisition, the development of students' meta-cognition, or their ability to understand and orchestrate their own learning process, has been urged by a number of language learning strategy researchers [11]-[13]. O’Malley and Chamot [14] (1990) considered learning strategies as cognitive skills. Learning strategies have been divided into three categories according to the level or type of processing involved [15]. They are metacognitive strategies, cognitive strategies, and social/affective strategies. Meta-cognitive strategies are higher order executive skills that may entail planning for, monitoring, or evaluating the success of a learning activity as shown in Table 1.

\section{Research Methods}

\subsection{Subjects}

In September 2014, 183 second-year non-English-majored colleges in 6 classes from Yangtze University, Chinese as the main language. Their majors are chemistry, agriculture, plant protection, animal medicine, animal science and biological technology participated in this study. Among the 183 subjects, they were 103 females and 80males, average age 19. All 183subjects who had learned college English first year were randomly divided into the control group (CG 92 students) and the experiment group (EG 91 students). Their level of education, family background, age, personality and life experiences and other factors were same, that was to say, their overall learning and cognitive abilities were almost equal. All 183 students were taught by the same teacher with 15-year teaching experience.

\subsection{College English Writing Course}

The English writing course was one part of the 15-week college English course. The 15-week college English course was divided into three parts:

Listening and speaking, reading and writing, teacher-guided autonomous learning. Students were to have listening and speaking English three hours a week, whereas English reading and writing, teacher-guided autonomous learning three hours a week (total fifteen weeks). The same instructor was responsible for all three parts' English learning of one class. In order not to lessen the financial burden to the subjects, the textbooks they had were used in this study. The textbook for non-English-majored college students in the English reading and writing class was Horizon published by Foreign Language Teaching and Research Press. In total, there were ten units in Reading and Writing 2, and each unit included two passages (Text A and Text B) of the same topic and exercises. Usually, the instruction given by the teacher in the writing classes included three steps. Firstly, the teacher would write down a topic related to Text A or Text B for non-English-majored college students to analyze or discuss among them before they wrote a essay. Non-English-majored college students were given the information to write about a topic related to Text A or Text B, which was a scaffold for them from reading to writing. Secondly, after analyzing or discussing, non-English-majored students would be asked to write a essay according to the topic they had analyzed or discussed. Finally, the essays they completed were handed to the teacher to correct errors such as grammar and polish. Students need to work with texts under teachers' instruction,

Table 1. Learning strategies description.

\section{Meta-cognitive strategies}

Advanced organizers

Making a general but comprehensive preview of the concept or principle in an anticipated learning activity.

Advance preparation

Planning for and rehearsing linguistic component necessary to carry out an upcoming language task.

Self-monitoring

Correcting one's speech for accuracy in pronunciation, grammar, vocabulary,

or for appropriateness related to the setting or to the people who are present.

Self-evaluation Checking the outcomes of his language learning against an internal measure of completeness and accuracy.

(Taken from O’Malley and Chamot’s classification of learning strategies, 1990). 
being exposed to different genres and topic areas, thinking about what they have read, forming preliminary ideas of their own, sifting through those ideas, and then finally beginning to organize them for writing: clustering, outlining, drafting, redrafting, revising, proofreading or editing. All of these aspects of a writing lesson help students develop their writing skills [16].

\subsection{Meta-Cognitive Strategy Training Program in IBLL}

For the students in CG, the regular non-English-major college English writing lessons with the method of students writing essays according to the topics given by the teacher then the teacher correcting errors such as grammars or mistakes in essays were taught in English writing lessons. For the students in EG, over the one-semester (15-week) period, the model of KWL plus was regarded as the major approach in this meta-cognitive strategy instruction in IBLL. The two passages in one unit of the reading and writing textbook were given as materials for this training. Without training to use what they know, their knowledge too often remains inert during essay [17]. Text A was used for the teacher modeling of strategy use in the Writing session and Text B for students' practice in the autonomous learning session to practice writing essays according to the requirements. One cycle of strategy training to the completed learning of one unit made up of scaffolding KWL plus with Text A and students' practice with Text B in IBLL for the teacher's intervention (scaffolding KWL plus with Text A), the teacher showed students how to move the information of writing skills known by students from Text A (K), then students wanted to know (W) how to write a essay from the beginning, the body and the conclusion from Text A or through the help of IBLL to look for information related to the essay they wanted to write, according to Covey's observation, Chinese students have two problems in writing: "they are worried that they have nothing to say; but if they have something to say they are worried that what they have said will not be understood" [18], and students learned (L) the writing skills by monitoring their writing essays, and finally Plus level was that subjects practiced writing essays after class, and subjects who completed their essay might exchange their rough drafts for making specific suggestions for improvement with classmates or by discussing their essays with writing teachers or professional writers online in IBLL. Repeated practice writing essays was an important step for non-English-majored college students to apply the writing skills they learned from the class to the real writing essay. Practice can markedly improve college students' writing ability when it is done in the context of a professionally relevant task domain that motivates efforts to learn [17]. Johnstone, Ashbaugh, and Warfield [19] found that superior writing skills correlated reliably with the degree of repeated practice and, controlling for practice, with writing in the professionally relevant domain of greatest interest to the students. Student needed enough hours to practice writing skills in writing essays, like the very best violinists, for example, have accumulated more than 10,000 hours in solitary practice, whereas lesser experts (7500 hr), least accomplished experts $(5000 \mathrm{hr}$ ), and amateurs (1500 hr) have devoted proportionally less time to self-improvement [20]. Discussion on writing essays was regarded as the feedback of non-English-majored college students' writing skills from the teacher. Such feedback is recognized as a powerful learning aid [21]. Although the KWL plus model was used through this whole semester, each round of training had a deliberate focus on one particular part of the cycling. For instance, each of the four main writing strategies trained in the KWL plus model constituted a focus on different rounds of training respectively in IBLL. Before non-English-majored college students wrote essays, they were taught to use the strategies of advanced organizers and advanced preparation; during the process of writing, they were taught to apply the strategy of self-monitoring to generate the essay, and they were taught to apply the strategy of self-evaluation to review the essays after the essays they wrote completed.

\subsection{Data Collection and Data Analysis}

In order to check the effects of KWL plus strategy training on non-English-major colleges' writing ability, two types of instruments were employed in this study: writing tests and interview.

Writing tests. Non-English-major colleges' writing tests were measured by pre- and post-tests. In order to avoid the interference of the author's subjectivity in test design and scoring, writing tests were measured directly by the part of writing in a nationwide standard test new version College English Test four (CET 4 710). NonEnglish-major colleges' writing scores were collected. Interview. To find out non-English-major colleges' response to this new approach to non-English-major colleges' English writing skills, their attitudes, problems, perception of benefits and predicted future use of this method were gathered through an interview on the KWL plus model of meta-cognitive writing strategies in IBLL with EG in the last English class. They were totally free 
to decide on their own whether to participate in attending the interview.

At the end of the semester, the collected data of subjects' pre-and post-writing test scores were processed with SPPS 15.0. An independent samples t-test was used to find if there were differences between EG and CG preand post-tests. Data of the interview were analyzed and categorized according to questions asked in the interview.

\section{Results}

The findings in this study were shown in three parts. Part One was writing test results of CG and EG. Part Two was that whether there are significant differences between males and females, as a teacher-dominated approach with CG is compared with the KWL plus model of writing strategy instruction in IBLL with EG. Part Three examined perceptions of the meta-cognitive strategy instruction in IBLL from non-English-major colleges in EG.

\subsection{KWL plus Strategy Instruction in IBLL and Writing}

As shown in Table 2, the impact of the KWL plus model of meta-cognitive writing strategy instruction on non-English-major colleges' writing was measured by comparing writing tests' (CET 4) scores between CG and EG in the pre-and post-tests. In the pre-tests, there was no significant difference between CG $(\mathrm{M}=57.49, \mathrm{~S}=$ 11.29) and $\mathrm{EG}(\mathrm{M}=57.26, \mathrm{~S}=11.22)$ in their writing tests, $\mathrm{P}=0.368$. However, in the post-test, there was a significant difference between $C G(M=58.63, S=10.30)$ and $E G(M=60.89, S=10.43)$ in the writing test, $P=$ 0.001 .

\subsection{Results of the t-Test about Males and Females in CG and EG}

As shown in Table 3, there were significant differences between males and females in CG and EG. Males (P = 0.004) suggested that there was the significant difference between CG and EG and females $(P=0.003)$ suggested that there was the significant difference between CG and EG in their writing ability.

\subsection{Perceptions of KWL plus Model of The Meta-Cognitive Writing Strategy Instruction in IBLL from Non-English-Major Colleges in EG}

The interview on the meta-cognitive writing strategy instruction in IBLL from non-English-major college students in EG was administered to all subjects in EG at the end of the semester (January, 2015) to examine their responses for this integrated teaching method and to identify the possible benefits and problems of this program.

Among the 91 subjects in EG, 50 subjects said that the integrated teaching method of KWL plus model of the meta-cognitive writing strategy instruction in IBLL was practical for them to do English writing and they were also willing to try this combination in writing essays in the future; 21 subjects indicated that the method of KWL plus model of the meta-cognitive writing strategy instruction in IBLL provided them a new method on how to

Table 2. Effects of the KWL plus model of meta-cognitive strategy instruction on non-English-major colleges' writing.

\begin{tabular}{cccccc}
\hline \multirow{2}{*}{ Troups } & \multicolumn{2}{c}{ CG (N = 92) } & \multicolumn{2}{c}{ EG (N= 91) } & P \\
\cline { 2 - 5 } & M & S & M & S & \\
Pre-test & 57.49 & 11.29 & 57.26 & 11.22 & 0.368 \\
Post-test & 58.63 & 10.30 & 60.89 & 10.43 & $0.001^{* *}$ \\
\hline
\end{tabular}

$\mathrm{M}$ stands for mean; S stands for standard deviation; ${ }^{*} \mathrm{P}<0.05 ;{ }^{* *} \mathrm{P}<0.01$.

Table 3. Results of the t-test about males and females in CG and EG.

\begin{tabular}{cccc}
\hline T ( two-tailed) & Gender & Males & Females \\
\hline Probability & 0.004 & 0.003 \\
\hline
\end{tabular}


write a essay from reading they know as an example to what they want to know such as how to write the beginning, the body and the conclusion of the essay, they could have words to say in writing essays and knew how to write correct sentences in essays, then they learned the writing skills applied to practicing writing essays after class; 10 subjects said that they had not been afraid of writing essays when they learned the method of KWL plus model of the meta-cognitive strategy instruction in IBLL to write essays. The major benefits of employing KWL plus in writing in the support of IBLL were shown at three aspects. First, non-English-majored college students were instructed and trained by the KWL plus model of meta-cognitive writing strategies with the support of IBLL, they became active writers because more planning and ideas related to the writing topic were generated before they wrote the essay and they could be more easily to discuss their essays with classmates, writing teachers or other people with the help of IBLL. Second, non-English-majored college students could increase their meta-cognitive knowledge about themselves, the tasks and the writing strategies they should employ. 10 subjects said that they also learned to regulate their strategy use through continuous attention to their writing process. Third, duo to KWL plus strategy training in IBLL, they not only visualized and consolidated their writing ability through practicing writing essays and discussing their essays, also applied the KWL plus model of meta-cognitive writing strategies into the more new writings and communicated with more people about KWL plus model of meta-cognitive writing strategies with the help of IBLL.

\section{Discussion}

This paper wants to look for the answers to the three questions. One of the purposes in this study is to know if the KWL plus model of meta-cognitive writing strategy instruction through IBLL can improve non-Englishmajored colleges' writing skills. Subjects' improvement in writing skills shows the important role of meta-cognition played in their writings.

Chamot [22] identified good language learners as active learners who monitored their comprehension by continuous self-questioning, related new information to their own prior knowledge, knew how to make use of their prior knowledge, and made inferences about possible meanings. The KWL plus approach promotes learners' active involvement in their writing process via pre-writing (planning), during-writing (generating) and post-writing (reviewing) activities. Before the test, subjects in CG and EG, their writing scores was not significant difference. However, after the test, subjects in CG and EG, their writing scores was significant difference. That is to say, the method of KWL plus model of meta-cognitive writing strategy instruction through IBLL can improve nonEnglish-majored colleges' writing level.

After instruction and training by the model of KWL plus of meta-cognitive strategies, male and female non-English-major college students in EG successfully learn and apply the meat-cognitive strategies in writing new essays in IBLL, they show better in writing, compared with male and female non-English-major colleges in CG. And there are significant differences between Males and Females in CG and EG.

Non-English-major colleges in EG generally holding positive response for the KWL plus model of metacognitive strategy training program suggest that the combination of meta-cognition writing training and IBLL into regular EFL curriculum is a worthy try. Non-English-majored college students need practice writing more academic papers related to their majors, the method of KWL plus model of meta-cognitive writing strategy instruction and the support of IBLL is practical method for them to learn writing skills and apply the writing skills they learn to practice writing essays and academic papers. Although subjects in EG could learn the KWL plus model of meta-cognitive strategies with the support of IBLL, they also need the help from teaches. A teacher in Covey's study commented that the students were marked down for "lack of development but the students just cannot think of anything to say", so that examiners concluded their writing was "long, general, rambling and imprecise" [18] and that they lacked or ignored world knowledge on geography, politics and economics etc. [18]. Teachers need to help students build background knowledge if it is not presented [23], and achieve the balance between explicit strategy instruction, language learning and use of IBLL.

\section{Limitations and Suggestions for Further Research}

Though the present study has provided a comparatively detailed description of the KWL plus model of writing strategy instruction through IBLL applied among some non-English-majored college students, there are still some limitations of the study. Having the limitations in mind, suggestions for further research, therefore, can be put forward at the same time in order to achieve a lot thorough understanding of the KWL plus model of writing 
strategy instruction through IBLL.

Firstly, being time limitation (only a term) and other practical restrictions such as the subjects in the study consisted of only 183 non-English-majored college students in one university need to be broadened in further research.

Secondly, the instruments used to investigate non-English-majored college writing strategy instruction with the KWL plus model through IBLL involve the interview and tests. The study would be much better, if it were combined with other instruments such as observation, verbal report. More instruments should be used in investigation in further research.

Finally, the KWL plus model of writing strategy instruction through IBLL applied in non-English-majored college English writing can improve non-English-majored college students' English writing skills, but the KWL plus model of writing strategy instruction through IBLL also works for other subjects such as graduate students, we need further research.

Despite of the restraints of the study, it is hoped that it can offer some guidelines for further research on the KWL plus model through IBLL applied in English teaching.

\section{Conclusion}

183 non-English-major colleges from Yangtze University are participated in the one-term experiment in this study. 92 non-English-majored college students are regarded as subjects in the control group (CG) and 91 non-English-majored college students are regarded as subjects in the experimental group (EG). The results showed that 1) compared with a teacher-dominated approach for CG, internet-based language laboratory with KWL plus model meta-cognitive writing strategy instruction for EG did a better job in enhancing students' writing skills; 2) there were significant differences between males in CG and EG, and females in CG and EG; 3) students in EG held the positive response for the combined teaching method. The combination of the KWL plus model of meta-cognition strategy instruction and IBLL into the regular EFL curriculum is a better try to improve non-English-majored college students' writing skills. However, there are still more questions needed to solve. For example, this method of KWL plus model of the meta-cognitive writing strategy instruction in IBLL will work for other subjects such as high school students. We hope this paper will provide some information for other researchers' study on writing skills.

\section{References}

[1] Önkaú, N.A. (2009) Poetry Teaching in Laboratory Setting. Procedia-Social and Behavioral Sciences, 1, $590-595$. http://dx.doi.org/10.1016/j.sbspro.2009.01.106

[2] Yi, L. and Gao, X.-Y. (2011) Practice of Autonomous Learning Mode under the Language Laboratory Environment. Research and Exploration in Laboratory, 7, 327-329.

[3] Ustatia, M.K. and Ismail, I.S. (2013) Challenges Faced by Malaysian Polytechnic English Lecturers in Utilizing Digital Language Lab. Procedia-Social and Behavioral Sciences, 90, 365-373.

http://dx.doi.org/10.1016/j.sbspro.2013.07.104

[4] Ogle, D. (2009) Eating Contexts for Inquiry: From KWL to PRC2. Knowledge Quest, 38, 56-61.

[5] Ogle, D. (1986) K-W-L: A Teaching Model That Develops Active Reading of Expository Text. The Reading Teacher, 39, 564-570. http://dx.doi.org/10.1598/RT.39.6.11

[6] Carr, E. and Ogle, D. (1987) KWL Plus: A Strategy for Comprehension and Summarization. Journal of Reading, 30, 636-631.

[7] Ogle, D. (2007) Coming Together as Readers: Building Literacy Teams. 2nd Edition, Corwin Press, Thousand Oaks.

[8] Graham, S. and Harris, K.R. (2000) The Role of Self-Regulation and Transcription Skills in Writing and Writing Development. Educational Psychologist, 35, 3-12. http://dx.doi.org/10.1207/S15326985EP3501_2

[9] Zimmerman, B.J. and Risemberg, R. (1997) Becoming a Self-Regulated Writer: A Social Cognitive Perspective. Contemporary Educational Psychology, 22, 73-101. http://dx.doi.org/10.1006/ceps.1997.0919

[10] Flavell, J.H. (1976) Metacognitive Aspects of Problem Solving. In: Resnick, L.B., Ed., The Nature of Intelligence, Lawrence Erlbaum Associates, Hillsdale, 231-235.

[11] Anderson, N.J. (2002) The Role of Meta-Cognition in Second Language Teaching and Learning. ERIC Digest (Vol. April 2002), Center for Applied Linguistics, Washington DC.

[12] Rubin, J. (2001) Language Learner Self-Management. Journal of Asian Pacific Communication, 11, 25-37. 
http://dx.doi.org/10.1075/japc.11.1.05rub

[13] Wenden, A.L. (2000) Learner Development in language learning. Applied Linguistics, 23, 32-55. http://dx.doi.org/10.1093/applin/23.1.32

[14] OMalley, J. and Chamot, A. (1990) Learning Strategies in Second Language Acquisition. Cambridge University Press, Cambridge.

[15] O’Malley, J.M. and Chamot, A.U., Stewner-Manzares, G., Kupper, L. and Russo, R.P. (1985) Learning Strategies Used by Beginning and Intermediates ESL Students. Language Learning, 35, 21-46. http://dx.doi.org/10.1111/j.1467-1770.1985.tb01013.x

[16] Carrell, P.L., Pharis, B. and Liberto, J. (1989) Meta-Cognitive Strategy Training for ESL Reading. TESOL Quarterly, 23, 647-678. http://dx.doi.org/10.2307/3587536

[17] Kellogg, R.T. and Raulerson III, B.A. (2007) Improving the Writing Skills of College Students. Psychonomic Bulletin \& Review, 14, 237-242. http://dx.doi.org/10.3758/BF03194058

[18] Covey, M. (1983) Why Chinese Students Fail English Essay Tests: The Intimate Connection between Culture and Language. International Education Forum, 2, P1-6.

[19] Johnstone, K.M., Ashbaugh, H. and Warfield, T.D. (2002) Effects of Repeated Practice and Contextual-Writing Experiences on College Students' Writing Skills. Journal of Educational Psychology, 94, 305-315. http://dx.doi.org/10.1037/0022-0663.94.2.305

[20] Ericsson, A., Krampe, R.T. and Tesch-Romer, C. (1993) The Role of Deliberate Practice in the Acquisition of Expert Performance. Psychological Review, 100, 363-406. http://dx.doi.org/10.1037/0033-295X.100.3.363

[21] Metcalfe and Kornell (2007) Principles of Cognitive Science in Education: The Effects of Generation, Errors, and Feedback. Psychonomic Bulletin and Review, 14, 225-229. http://dx.doi.org/10.3758/BF03194056

[22] Chamot, A.U. (1995) Learning Strategies and Listening Comprehension. In: Mendelsohn, D. and Rubin, J., Eds., A Guide for the Teaching of Second Language Listening, Dominie Press, San Diego, 13-30.

[23] Duke, N. (2004) The Case for Informational Text. Educational Leadership, 61, 40-44.

\section{Submit or recommend next manuscript to SCIRP and we will provide best service for you:}

Accepting pre-submission inquiries through Email, Facebook, LinkedIn, Twitter, etc.

A wide selection of journals (inclusive of 9 subjects, more than 200 journals)

Providing 24-hour high-quality service

User-friendly online submission system

Fair and swift peer-review system

Efficient typesetting and proofreading procedure

Display of the result of downloads and visits, as well as the number of cited articles

Maximum dissemination of your research work

Submit your manuscript at: http://papersubmission.scirp.org/ 